\title{
FILM PREFERENCES IN THE PANDEMIC: PSYCHOLOGICAL RESILIENCE OR AN ESCAPE FROM THE PANDEMIC REALITY?
}

\author{
Jolanta Pisarek $^{1}$ and Emilia Zabielska-Mendyk ${ }^{2}$ \\ ${ }^{1}$ Independent researcher \\ ${ }^{2}$ John Paul II Catholic University of Lublin, Department of Experimental Psychology
}

\begin{abstract}
During the last year, the one of COVID-19 pandemic, the lives of many people have changed in many ways, one of them is media consumption. We wanted to verify whether "stay at home" recommendations influenced viewers' preferences concerning films, their watching habits, motivation to choose a specific film and how media use is related to some psychological variables, mainly a sense of loneliness, self-esteem and pandemic psychological resilience. Results of the online survey showed that participants watch more films or series during the pandemic than before and that they prefer various genres. They more often use streaming platforms and go to the cinema less frequently compared to the period before the pandemic. Participants watch films more for both entertainment and as a way to get away from everyday reality than before. Cast, film topic and recommendations became less important when choosing a film. There was also found a weak, however significant correlation between describing oneself as a fan of a specific film genre and the pandemic psychological resilience. Results show that the pandemic psychological resilience is moderately, negatively related to loneliness. A positive, however weak, relation of pandemic psychological resilience to self-esteem was also found.
\end{abstract}

Keywords: film preferences; COVID-19; film perception; resilience; loneliness; self-esteem.

Jolanta PisareK, https://orcid.org/0000-0002-7759-2425, Emilia ZabielsKa-MendyK, https:// orcid.org/0000-0002-7858-4347.

Correspondence concerning this article should be addressed to EmiLIa ZabielsKA-MendYK, Katolicki Uniwersytet Lubelski Jana Pawła II, Katedra Psychologii Eksperymentalnej, Al. Racławickie 14, 20-950 Lublin, Poland; email: zabielska.emilia@op.pl.

Handling editors: Magdalena Szubielska \& Pawę StróżaK, John Paul II Catholic University of Lublin.

Received 5 May 2021. Received in revised form 20 October 2021, 8 December 2021. Accepted 19 December 2021. Published online 24 February 2022. 


\section{INTRODUCTION}

\section{Patterns of Film Watching in the Pandemic}

The audience statistics of one of the most popular streaming platforms (Netflix) inform us about several phenomena that took place in the year of the COVID-19 pandemic. First, at the beginning of the pandemic, there was an increase in the popularity of pandemic-themed disaster films. Secondly, the platform's 2020 audience statistics summary indicates a 500\% increase in the interest in fantasy films among its users compared to the previous year. Thirdly, the audience were three times more likely to turn to romantic comedies and musicals (Kołodziej, 2020).

The first phenomenon, according to the approach that treats a film as a simulated experience, seems to address the viewers' need to be prepared for various pandemic scenarios in the real world (Scalise-Sugiyama, 2001; Scrivner et al., 2021). But the other two may indicate more of a need to detach from reality, either cognitively (experience an unrealistic world in a fantasy film or a predictable scenario in a romantic comedy) or emotionally (the need to experience positive emotions).

The main goal of our study is to explore the film watching patterns in the pandemic and answer the question whether the pandemic reality has affected the frequency of viewing, film preferences, viewing motives and factors that determine film choice. This way we provide the test of the main paradigm of the cognitive psychology of film, according to which the basis for film reception is the film knowledge and film experience of the viewer (Bordwell, 1985). Our study concentrates on viewers' attitudes and motivations, and examines the relation between the pandemic resilience and film preferences, as well as with other psychological constructs. We were particularly interested in loneliness and self-esteem. Latest research shows that restrictions in social life and economic losses can result in psychological and emotional consequences such as demotivation, loss of meaning and decreased selfworth (Williams et al., 2020). Consequently, pandemic situation would influence self-esteem, while loneliness would be related to the social distancing and isolation which was forced both by lockdown and recommendations for avoiding the infection. Scrivner et al. (2021) have already shown, that fans of horror films and "prepper" genres exhibit greater pandemic resilience. Their results are congruent with the hypothesis on how exposure to fearful fictions can lead to engaging in coping strategies beneficial in real-world situations. However, it would be worth finding out whether pandemic resilience apart from being related to film preferences is also related to psychological factors which can be affected by pandemic situation. 


\section{The Role of Viewers' Motivation and Needs in Building a Coherent Film Story}

Filmmakers more or less try to reflect reality in films. However, on a perceptual level film is received by viewers exactly like the reality is. The suspicion that film is subject to the laws of mind rather than the laws of the external world, which means the world outside the one of viewers', was for the first time articulated over 100 years ago by the psychologist and philosopher Hugo Münsterberg. His book The Photoplay. A Psychological Study (1986) gave birth to the paradigm of the contemporary cognitive psychology of film, which put the role of both structural features of film and viewers' knowledge in film comprehension at the heart of researchers' interest. Parallelly Peter Ohler (1999) highlighted that "cognitive film theory does not address the question of constructing socio-psychological descriptions of the attitudes, preferences, motivations, and needs of the viewer in question, but stops at describing and predicting his cognitive processes" (p. 330).

Viewers' motivation, next to the criterion of novelty or unpredictability, is the most important factor that determines the distribution of cognitive resources being allocated in the process of building a coherent film story. The factors listed above are the most frequent determinants examined within the model of the limited capacity of mediated message processing (Lang, 2000; Francuz, 2002). While watching a film viewers need to constantly encode and store film data and simultaneously retrieve the information from their long-term memory to understand the film. A film containing information contrary to viewers' expectation or previous experience is frequently a real cognitive challenge, because it may slow down the film comprehension process (Branigan, 1999).

According to the use and gratification theory (Turska-Kawa, 2013), audience experiences and expectations motivate or discourage specific media use. Film, like other media messages, is intended to gratify the needs of the audience. Denis McQuail (2008) synthetically classified the needs of individuals and society that the media respond to. First, there is the need for information. Media satisfies the curiosity of viewers, it is where they seek advice and support. Second, individuals also seek in the media confirmation of their own value system, thus shaping their identity. Third, media satisfy the need to be affiliated, providing benefits in the area of integration and social interaction. And finally, they can be a source of entertainment, on the one hand helping to relax and to fill leisure time, on the other distracting from problems. In other words, as Turska-Kawa (2013) points out while referring to Epstein's cognitive-experiential self-theory, viewers, in their search for entertainment in the media, are primarily driven by the need to obtain pleasure and avoid pain. In turn, the need 
for identity formation satisfied by the media is said to respond mainly to the need to enhance self-esteem (Polański, 2017). All of the indicated needs can affect film preferences and film reception in a different way, speeding up or slowing down the process of film comprehension. What's more, these functions are not separate, but interact with each other. The same film can provide different psychological benefits.

In this study we want to provide a description of viewers' motivation and film preferences with reference to two periods, before and during the pandemic, and answer the following questions:

Has the number of films watched per week changed?

Has the frequency of use of particular media to watch films changed?

Has the function of watching films changed?

3.1. Has the informational function of watching films changed?

3.2. Has the entertainment function of watching films changed?

3.3. Has the emotional function of watching films changed?

Have the factors/motives for choosing films changed?

Also, we were interested in the relation of pandemic resilience with two psychological variables and we wanted to investigate if:

Is there a relationship between pandemic resilience and loneliness?

Is there a relationship between pandemic resilience and self-esteem?

\section{METHOD}

\section{Participants}

200 individuals ( 143 women, 57 men) completed the online film survey and psychological questionnaires. The mean age was 33.7 years old $(M=33.7$; $S D=9.49)$. Most of the participants work remotely full time (38.5\%), some of them work remotely most of the week (19\%) or in the mixed system (16\%). $22 \%$ of the participants do not work remotely. For $4.5 \%$ of the participants the question was not applicable, because they do not have a job. $44 \%$ of the participants declared they do have contact with other people at work, while $48.5 \%$ declared no contact, for the rest of participants (7.5\%) the question was not applicable. Only $12.5 \%$ of the participants live alone, while more than a half (52.5\%) live with their family, a roommate $(10 \%)$ or a partner $(22.5 \%)$. The remaining $2.5 \%$ have chosen the answer "other". Only $15.5 \%$ of the participants declared that they have not restricted their social activity during the pandemic. $63 \%$ of the participants declared that they watch films more often or definitely more often during the pandemic and $62 \%$ declared 
that they watch series more often or definitely more often during the pandemic (see Appendix: Table 1). Figure 1 presents the genres participants declared to watch most often before and during the pandemic. Ranking the declarations showed that both during and before the pandemic, comedies, dramas, and crime films were indicated in first, second, and third place, respectively. Additionally, 84 participants indicated that they were most interested in watching comedies during the pandemic and 76 participants before the pandemic. For drama, it was the most interesting genre for 66 participants during and 70 participants before the pandemic, for crime films 54 participants during and before the pandemic.

\section{Figure 1}

Number of Participants Preferring to Watch Films of a Particular Genre Before and During the Pandemic

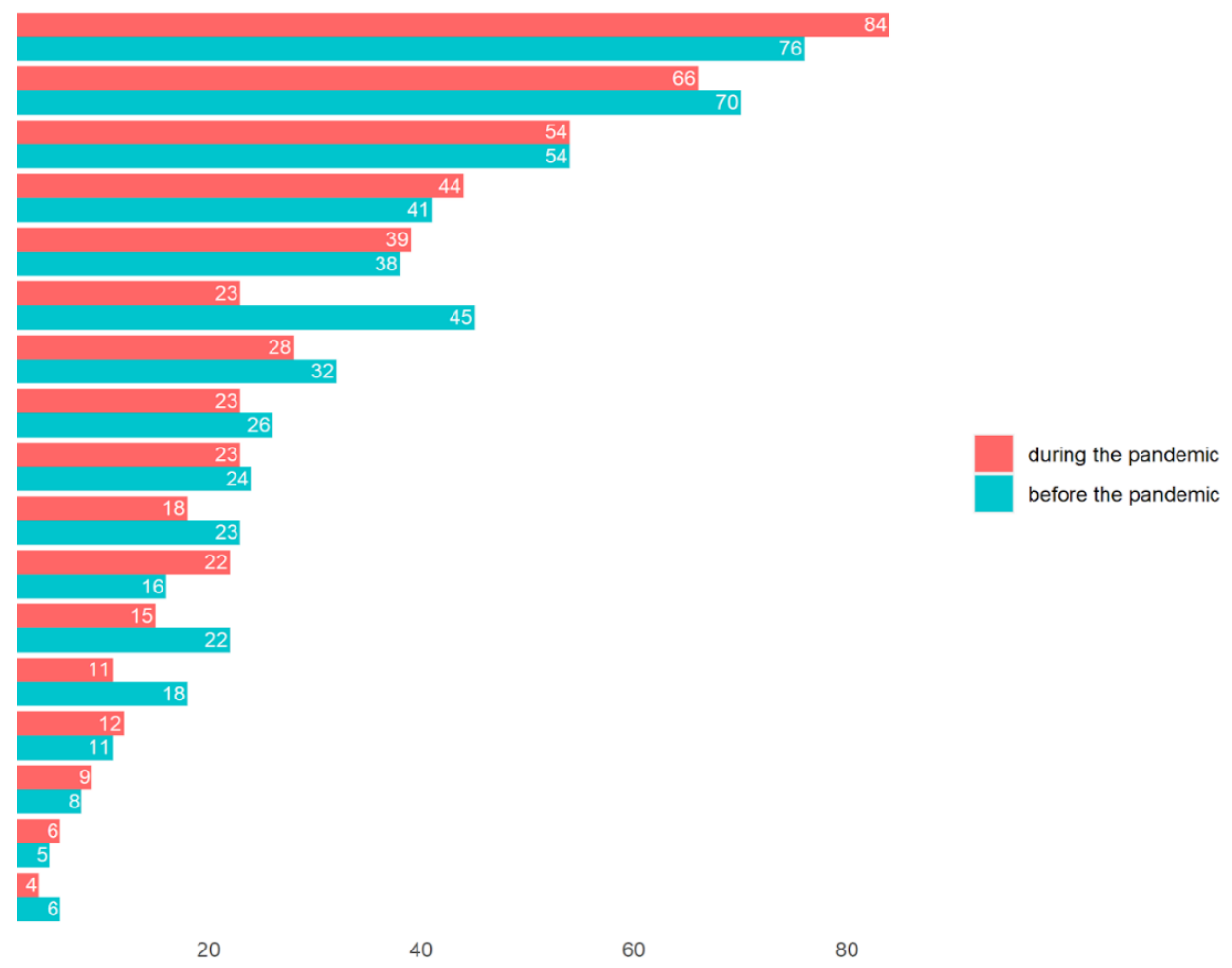

Note. Total number of participants watching films of all genres before the pandemic $N=547$, during the pandemic $N=515$. The difference is due to the character of the question: each participant was able to indicate up to three most watched genres. 


\section{Measures}

\section{Social Functioning during the Pandemic}

Participants were asked about their working and free time mode, daily habits and attitude to social interactions during the pandemic.

\section{Pandemic-Specific Questions}

In the main section of the survey respondents were asked about activities and preferences related to watching films and TV series with reference to two periods - before and during the pandemic. Both parts contained analogous questions or statements to finish about the amount of episodes or films watched per week ("On average, I watched ... films/series episodes per week"), genre preferences ("I have most often watched productions from the genre. Indicate up to three possibilities"), the place to watch films ("Where did you most often watch film? and the frequency for each location: 1-rarely, 7-often"), and question about the motivation to watch film ("For me, watching a film is: 1-strongly disagree, 7-strongly agree"). In this question we focused on three main functions of watching films. First is the entertainment function of film. The second one is the informational function corresponding to cognitive needs of viewers, who treat films as a source of knowledge. Last function addresses the emotional needs of viewers-escape from reality vs. readiness to experience specific emotions while watching a film. The last question concerned the characteristics of a film that determine the choice of a film to watch ("Which factors influenced your decision to choose a particular film to watch: 1 -definitely not influenced, 7-definitely influenced").

\section{Loneliness}

The De Jong Gierveld Loneliness Scale (DJGLS) in the Polish adaptation conducted by Grygiel et al. (2012) was used in the study. The Loneliness Scale is a 11-item assessment where participants rated each of them on a five-point scale ranging from definitely yes to definitely not. The reliability of the Polish adaptation of the scale is high $(\alpha=.89)$ and has a has a satisfactory validity criterion: correlation with the UCLA Loneliness Scale $r=.82$; with Rosenberg's Self-Esteem Scale $r=-.56$; and with the Beck Depression Inventory $r=.46$ (all $p<.01$ ). 


\section{Self-Esteem}

To measure the global self-esteem we used The Rosenberg self-esteem scale (RSES) in the Polish adaptation conducted by Dzwonkowska et al. (2008). The Rosenberg Self-Esteem Scale consists of 10 statements related to overall feelings of self-worth or self-acceptance. Participants were instructed to rate on a four-point scale (from strongly agree to strongly disagree) how much they agreed or disagreed with each of the 10 statements. The value of the reliability coefficient of the Polish version of the scale in different study groups ranges from .81 to .83 . is high $(\alpha=.81-.83)$. The scale has a satisfactory validity criteria, as determined by its relationship to scales measuring emotional and social functioning.

\section{Psychological Resilience}

To assess the psychological resilience during the pandemic we used the Polish translation of The Pandemic Psychological Resilience Scale (PPRS) created by Scrivner et al. (2021). For the purpose of their study (2021) they operationalized resilience as the ability to have more positive experiences/emotional states (positive resilience) or fewer negative experiences/emotional states (psychological distress). In contrast to general event-resilience scales PPRS is well-suited for a longterm event with a somewhat abstract threat (e.g. a pandemic). Participants rated on a 7-point scale (strongly disagree to strongly agree) how much they agreed or disagreed with each of 13 statements. The scale demonstrated adequate internal reliability $(\alpha=.73)$. The Polish version of the scale was translated using the back translation procedure and its final translation was corrected by the author of the original PPRS.

\section{Procedure}

Data was gathered via Google Surveys between 9th March 2021 and 13th April 2021, exactly one year into the pandemic in Poland. Participants were recruited for the study through advertisements posted on social media sites, mainly Facebook, and by announcements sent to the students via MS Teams platform used for the remote learning. The link to survey was posted on Facebook groups of film scholars and film festival fans such as the "Akcja Filmoznawca" group and "Nowe Horyzonty po godzinach" group, as well as on groups for students of e.g. the University of Warsaw. 


\section{RESULTS}

\section{Frequency of Film Watching in the Pandemic}

Data was analyzed with the IBM SPSS Statistics version 27. The results show that there are significant differences in the amount of films or episodes watched (McNemar-Bowker test: $\operatorname{chi}^{2}(8)=29.45 ; p<.001$ ). More participants declare they view 6-9 or 10 or more episodes or films during the pandemic per week than they did before. On the other hand, fewer participants declare they view 1-2 or 3-5 episodes or films during the pandemic per week than they did before (see Appendix: Table 2).

\section{Patterns of Film Watching in the Pandemic}

Results also indicate that participants more often use streaming platforms to watch films or series $(t(151)=7.07 ; p=.002$, Cohen's $d=0.57)$ and they go to the cinema less often currently than before the pandemic $(t(188)=-5.72 ; p=.004$, Cohen's $d=0.42)$. Other comparisons were insignificant $(p>.05)$ (see Appendix: Table 3).

\section{Motivation to Watch Films in the Pandemic}

There were also some significant differences concerning motivation to watch films before and during the pandemic. Mainly, during the pandemic participants watch films more for entertainment than before $(t(199)=2.16 ; p=.03$; Cohen's $d=0.15)$ and more as a way to get away from the everyday reality than before $(t(199)=4.67 ; p<.001$; Cohen's $d=0.33)$. Other comparisons were insignificant $(p>.05)$ (see Appendix: Table 4). In addition, there were some significant differences concerning factors related to choosing a particular film to watch before and during the pandemic. Results show that factors such as cast $(t(199)=2.79 ; p=.025$; Cohen's $d=0.20)$ and recommendations of streaming platforms $(t(199)=3.82$; $p=.005$; Cohen's $d=0.27$ ) were less important during the pandemic than before, there was also a tendency for lesser film topic role $(t(199)=2.18 ; p=.05$; Cohen's $d=0.16$ ). Other comparisons were insignificant $(p>.05)$ (see Appendix: Table 5). 


\section{Film Preferences and the Pandemic Resilience}

The correlation analysis showed that there was an association between the pandemic resilience and how strong a fan of certain film genres participants identified themselves as. The $p$ value was adjusted with Benjamini-Hochberg correction for multiple correlations. There was a weak but significant Pearson's $r$ correlation between the PPRS score and describing yourself as a fan of science fiction films $(r=.21 ; p=.03)$, and a trendtoward correlation for describing yourself as a fan of romantic comedies $(r=-.16 ; p=.06)$, the other correlations were insignificant $(p>.05)$.

Pandemic psychological resilience also correlated with other psychological measures, mainly loneliness and self-esteem. There was a moderate negative relationship between PPRS and loneliness $(r=-.43 ; p<.001)$ and weak positive relationship between PPRS and self-esteem $(r=.29 ; p<.001)$.

\section{Pandemic Resilience, Loneliness and Self-Esteem}

Pandemic psychological resilience also correlated with other psychological measures, mainly loneliness and self-esteem. There was a moderate negative relationship between PPRS and loneliness $(r=-.43 ; p<.001)$ and weak positive relationship between PPRS and self-esteem $(r=.29 ; p<.001)$.

\section{DISCUSSION}

The pandemic has changed the scenery of our everyday life and the way we perceive people's behaviors and interactions. Social interactions have been dominated by safety protocols like social distancing and wearing masks. In turn, leisure activities were largely determined by government restrictions and limited access to places where people gather, including film theatres. The limitations were reflected in the results of our study. Viewers were significantly more likely to use streaming platforms and less likely to go to the film theatres than before the pandemic. The pandemic also affected viewing frequency. More viewers declared that they watched a larger number of films or series during the pandemic than before. The responses received in the question about place where they watch films most often indicate the effect of spending more time at home. Compared to the pre-pandemic period the viewers are more likely to watch films or series to get away from the everyday real- 
ity or for entertainment. Interestingly, other motivations did not change during the pandemic. For the group who treat film watching as a hobby the lack of differences is not surprising, as this motivation is likely independent of external circumstances. Similarly, when treating films as a source of knowledge, which in this case may mean volitional exposure to films about the pandemic and to fears associated with them. This motivation may be characteristic mainly for a group of fans of so-called "prepper" genres (apocalyptic, alien-invasion, zombie films). And as Scrivener's and colleagues' study showed (2021), interest in the pandemic films during the pandemic is associated with pandemic preparedness and morbid curiosity of the viewers. In other words, it can only apply to a group of film fans who prefer the confrontation with the emotion of fear over the avoidance mechanisms. Results of our study point to viewers' avoidance motivation (the need to get away from reality) rather than a confrontational tendency. On the other hand, the lack of differences in the educational motivation may have been due to the fact that the need to treat pandemic films as a source of knowledge, in reference to audience statistics, has been limited in time and occurred only during the initial period of the pandemic.

Apart from comparing viewers' film preferences and their motivation for watching films before and during the pandemic, we tested the relation between the psychological pandemic resilience and film preferences. The analysis showed a weak, but significant correlation for the science-fiction genre and the tendency towards correlation for romantic comedies. The more strongly the participants described themselves as fans of science-fiction, the higher their resilience was. On the other hand, the more strongly the participants declared themselves as fans of romantic comedies, the lower the resilience was. The correlations obtained, as with the Scrivener's and colleagues' study, may indicate the presence of the mediating variable in explaining the correlation. In the case of science fiction such a construct could be the attitude to knowledge or general psychological resilience, in the case of fans of romantic comedies, the attitude where social interactions are the primary source of meaning in life. Considering the pandemic has changed the perception of social interactions, it will also be interesting to examine if the pandemic changes our cognitive schemas about people's interaction in a way that disrupts the viewers' engagement in the contemporary films. Our results also have shown that not only pandemic resilience is related to film preferences but also to psychological factors which are linked to pandemic situation. Changes in social life enforced by pandemic restrictions and recommendations may less affect people with greater pandemic resilience which is related to lower loneliness and higher self-esteem. 


\section{Limitations}

Although results of the study shed some light on media consumption during the pandemic, there are some limitations of the current study that are worth mentioning. The data collected came from self-reports of the participants. It would be valuable to compare the declarations of the subjects with the actual level of media consumption. Additionally, the majority of participants in the study were women, which can lead to questions whether the results are not gender biased. However, when it comes to television and film consumption, men and women watch tv and films with a similar frequency and go to the cinema similarly often, and differences are revealed at the level of preferences for most film genres (Wühr et al., 2017).

\section{CRediT Author Statement}

Jolanta PisareK (50\%): conceptualization, methodology, software, resources, writing (original draft), supervision, writing (review and editing), visualization.

EMILIA ZABIELSKA-MENDYK (50\%): conceptualization, methodology, software, validation, formal analysis, resources, writing (original draft), writing (review and editing), visualization.

We have no conflict of interest to disclose. We had no financial support. We would like to thank Coltan Scrivner from the University of Chicago for permission to use Polish translation of the Pandemic Psychological Resilience Scale (PPRS) in our study.

\section{REFERENCES}

Bordwell, D. (1985). Narration in the fiction film. University of Wisconsin Press.

Branigan, E. (1999). Schemat fabularny [Plotline]. In J. Ostaszewski (Ed.), Kognitywna teoria filmu. Antologia przekładów (pp. 112-154). Wydawnictwo Baran i Suszyński.

Dzwonkowska, I., Lachowicz-Tabaczek, K., \& Łaguna, M. (2008). Samoocena i jej pomiar SES. Polska adaptacja skali SES M. Rosenberga [Self-esteem and its measurement SES. Polish adaptation of the SES scale by M. Rosenberg]. Pracownia Testów Psychologicznych.

Francuz, P. (2002). Rozumienie przekazu telewizyjnego. Psychologiczne badania telewizyjnych programów informacyjnych [Understanding the television broadcast. Psychological study of television news programs]. Towarzystwo Naukowe KUL.

Grygiel, P., Humenny, G., Rębisz, S., Świtaj, P., \& Sikorska-Grygiel, J. (2012). Validating the Polish adaptation of the 11-item De Jong Gierveld Loneliness Scale. European Journal of Psychological Assessment, 29, 129-139. https://doi.org/10.1027/1015-5759/a000130 
Kołodziej, E. (2020, December 10). Netflix podsumował mijający rok. Te filmy i seriale najchętniej oglądaliśmy w 2020 roku [Netflix has summed up the past year. These movies and series were the most watched in 2020]. Noizz.pl. https://noizz.pl/film/netflix-podsumowal-mijajacy-rok-tonajchetniej-ogladali-polacy/5tvg9x9

Lang, A. (2006). The limited capacity model of mediated message processing. Journal of Communication, 50, 46-70. https://doi.org/10.1111/j.1460-2466.2000.tb02833.x

McQuail, D. (2008). Teoria komunikowania masowego [Mass communication theory] (Alina Szulżycka \& Marta Bucholc, Trans.). Wydawnictwo Naukowe PWN.

Münsterberg, H. (1989). Dramat kinowy. Studium psychologiczne [The Photoplay. A Psychological Study]. Łódzki Dom Kultury.

Ohler, P. (1999). Kognitywna teoria percepcji filmu. Koncepcja przetwarzania informacji [Cognitive theory of film perception. The concept of information processing]. In J. Ostaszewski (Ed.), Kognitywna teoria filmu. Antologia przekładów (pp. 330-345). Wydawnictwo Baran i Suszyński.

Polański, G. (2017). Gratyfikacje z korzystania z mediów [Gratifications of media use]. Edukacja - Technika-Informatyka, 8(3), 250-255.

Scalise-Sugiyama, M. (2001). Food, foragers, and folklore: The role of narrative in human subsistence. Evolution and Human Behavior, 22(4), 221-240. https://doi.org/10.1016/S1090-5138(01)00063-0

Scrivner, C., Johnson, J. A., Kjeldgaard-Christiansen, J., \& Clasen, M. (2021). Pandemic practice: Horror fans and morbidly curious individuals are more psychologically resilient during the COVID-19 pandemic. Personality and Individual Differences, 168, 110397. https://doi.org/10.1016/j. paid.2020.110397

Turska-Kawa, A. (2013). Media jako źródło zaspokajania fundamentalnych potrzeb. Rozważania w kontekście teorii ,użytkowania i gratyfikacji” [Media as a source of satisfying fundamental needs. Considerations in context of the ", uses and gratifications” theory]. Studia Politicae Universitatis Silesiensis, 10, 147-172.

Williams, S. N., Armitage, C. J., Tampe, T., \& Dienes, K. (2020). Public perceptions and experiences of social distancing and social isolation during the COVID-19 pandemic: A UK-based focus group study. medRxiv. https://www.medrxiv.org/content/10.1101/2020.04.10.20061267v1

Wühr, P., Lange, B. P., \& Schwarz, S. (2017). Tears or fears? Comparing gender stereotypes about movie preferences to actual preferences. Frontiers in Psychology, 8:428. https://doi.org/10.3389/ fpsyg.2017.00428 


\section{Appendix. A Tables}

\section{Table 1}

Summary of percentages of participants by frequency of watching films or series before and during pandemic

\begin{tabular}{lcc}
\hline \multicolumn{2}{l}{ How often do you watch films or series compared to before the pandemic? $(N=200)$} & \\
\hline & Films $(\%)$ & Series (\%) \\
\cline { 2 - 3 } Definitely less often & 1.0 & 1.5 \\
Less often & 2.5 & 4.0 \\
No change & 29.0 & 28.5 \\
More often & 32.0 & 31.0 \\
Definitely more often & 31.0 & 31.0 \\
Not applicable & 4.5 & 4.0 \\
\hline
\end{tabular}

\section{Table 2}

Summary of percentages of participants by amount of episodes or films watched before and during pandemic

The amount of episodes or films watched per week $(N=200)$

\begin{tabular}{lcc}
\hline & Before the pandemic $(\%)$ & During the pandemic $(\%)$ \\
\cline { 2 - 3 } 0 episodes/films & 3.5 & 3.0 \\
1-2 episodes/films & 26.5 & 19.5 \\
$3-5$ episodes/films & 38.0 & 33.5 \\
$6-9$ episodes/films & 16.5 & 19.0 \\
More than 10 episodes/films & 15.5 & 25.0 \\
\hline
\end{tabular}




\section{Table 3}

Mean, standard deviation and test of mode of watching films before and during pandemic

How do you most often watch films before and during the pandemic?

(1-definitely not often 7-definitely often)

\begin{tabular}{lccc}
\hline & Mean & Standard deviation & $t$ test for dependent measures \\
\cline { 2 - 4 } In cinema before & 3.06 & 1.87 & $t(151)=7.07 ; p<.001$ \\
In cinema during & 1.89 & 1.55 & \\
On TV before & 3.23 & 2.06 & $t(155)=0.41 ; p=.68$ \\
On TV during & 3.19 & 2.15 & $t(188)=5.72 ; p<.001$ \\
Via streaming before & 5.84 & 1.63 & \\
Via streaming during & 6.28 & 1.44 & $t(123)=0.41 ; p=.69$ \\
Via internet download before & 2.77 & 2.13 & \\
Via internet download during & 2.83 & 2.33 & \\
\hline
\end{tabular}

Note. The $p$ value was adjusted with Benjamini-Hochberg correction for multiple comparisons.

\section{Table 4}

Mean, standard deviation and test of motivation to watch films before and during pandemic

What was your motivation to watch films before and during the pandemic?

(1-definitely do not agree 7-definitely agree)

\begin{tabular}{|c|c|c|c|}
\hline & Mean & Standard deviation & $t$ test for dependent measures \\
\hline \multicolumn{4}{|l|}{ Entertainment function } \\
\hline For entertainment before & 5.19 & 1.81 & \multirow{2}{*}{$t(199)=-2.16 ; p=.03$} \\
\hline For entertainment during & 5.38 & 1.72 & \\
\hline As a hobby before & 3.80 & 2.13 & \multirow{2}{*}{$t(199)=-0.74 ; p=.46$} \\
\hline As a hobby during & 3.85 & 2.18 & \\
\hline $\begin{array}{l}\text { as a way to get away from the everyday } \\
\text { reality before }\end{array}$ & 4.44 & 2.03 & \multirow{2}{*}{$t(199)=-4.67 ; p<.001$} \\
\hline $\begin{array}{l}\text { as a way to get away from the everyday } \\
\text { reality during }\end{array}$ & 4.89 & 2.03 & \\
\hline \multicolumn{4}{|l|}{ Informational function } \\
\hline Source of knowledge before & 3.31 & 1.97 & \multirow{2}{*}{$t(199)=0.14 ; p=.89$} \\
\hline Source of knowledge during & 3.30 & 2.00 & \\
\hline \multicolumn{4}{|l|}{ Emotional function } \\
\hline For positive emotions before & 4.77 & 1.83 & \multirow{2}{*}{$t(199)=-1.25 ; p=.21$} \\
\hline For positive emotions during & 4.88 & 1.85 & \\
\hline To soothe negative emotions before & 3.42 & 1.98 & \multirow{2}{*}{$t(199)=-0.3 ; p=.72$} \\
\hline To soothe negative emotions during & 3.45 & 2.02 & \\
\hline To relax before & 5.37 & 1.72 & \multirow{2}{*}{$t(199)=-1.72 ; p=.09$} \\
\hline To relax during & 5.52 & 1.80 & \\
\hline
\end{tabular}

Note. The $p$ value was adjusted with Benjamini-Hochberg correction for multiple comparisons. 


\section{Table 5}

Mean, standard deviation and test of factors related to choosing a film to watch before and during pandemic

What are the factors related to choosing a particular film to watch before and during the pandemic?

(1-definitely not important 7-definitely important)

\begin{tabular}{lccc}
\hline & Mean & Standard deviation & t test for dependent measures \\
\cline { 2 - 4 } Film genre before & 5.72 & 1.49 & $t(199)=0.51 ; p=.61$ \\
Film genre during & 5.67 & 1.69 & \\
Cast before & 4.80 & 1.82 & $t(199)=2.79 ; p=.01$ \\
Cast during & 4.62 & 1.91 & $t(199)=1.69 ; p=.09$ \\
Director and other filmmakers before & 4.26 & 2.12 & $t(199)=2.18 . p=.03$ \\
Director and other filmmakers during & 4.13 & 2.06 & \\
Film topic before & 6.17 & 1.05 & $t(199)=3.82 ; p<.001$ \\
Film topic during & 6.00 & 1.26 & \\
Recommendations of streaming & 3.05 & 1.85 & \\
platforms before & & 1.76 & \\
Recommendations of streaming & 2.69 & & \\
platforms during & & & \\
\hline
\end{tabular}

Note. The $p$ value was adjusted with Benjamini-Hochberg correction for multiple comparisons. 